\title{
Effect of intensive planting density on tree growth, wood density and fiber properties of maple (Acer velutinum Boiss.)
}

\author{
Hamid Reza Naji ${ }^{(1)}$, Marziyeh \\ Fallah Nia ${ }^{(2)}$, Majid Kiaei( ${ }^{(3)}$, \\ Hazandy Abdul-Hamid ${ }^{(4)}$, \\ Mojtaba Soltani ${ }^{(3)}$, Ali Faghihi ${ }^{(2)}$
}

\begin{abstract}
Planting density is a major factor in determining tree growth and wood quality. Although the effect of low planting density on the variation of tree and wood characteristics has been already reported, the effect of intensive initial densities in plantations has not been fully assessed yet. In this study, the effect of intensive planting densities on tree growth, wood density and fiber cell properties was investigated in the context of the development of densely-stocked maple plantations for wood production. The study was carried out in a 12year-old Acer velutinum trial plantation in northern Iran, with initial densities of 10000,4444 , and 2500 trees $\mathrm{ha}^{-1}$ planted. The variation of diameter at breast height, annual ring width, stem taper, wood density, and fiber cell properties were examined. As expected, low planting densities showed trees with larger diameter at breast height and annual ring width. The largest trees at higher densities were smaller than those in lower planting densities. However, initial planting density had no significant effect on stem taper, wood density and fiber cell properties. In addition, no significant relationships between tree growth features and wood properties were detected, indicating similar wood properties at all planting densities. Therefore, stand/tree growth attributes under intensive planting densities could not be considered as reliable predictors of the wood properties.
\end{abstract}

Keywords: Initial Spacing, Annual Ring Width, Wood Density, Fiber Properties, Acer velutinum

\section{Introduction}

With increasing demand for wood products, there is an increasing pressure on forests to produce both higher quantities and quality of wood (Chaffey 2002, Clark et al. 2008). The development of large-scale plantations and agroforestry systems is important for meeting the demand and reducing wood shortages (Fujiwara \& Yang 2000). Maples (Acer spp.) are well-known as fast-growing tree species in temperate areas and are used in large-scale plantations (Fallah nia 2009).

Acer velutinum (Persian or velvet maple) is indigenous to the Hyrcanian forest (northern Iran) and makes up about 5.8\% of the

mixed forests therein, growing in a wide range of altitudes up to $2000 \mathrm{~m}$ a.s.l. (Yousef Zadeh 2007). Along with alder (Alnus spp.), it is a significant diffuse-porous hardwood in developing plantation programs This species belongs to the medium wood density group, and is used in the pulp and paper industry, in furniture and cabinet production, and as building material. It is also used to make veneer, plywood, strandboards and wooden utensils. Therefore, owing to its favorable properties, there is considerable potential to increase this resource (Fallah nia 2009).

Intensive management in plantations affects growth features, biomass and wood $\square$ (1) Department of Forest Sciences, Ilam University, Ilam (Iran); (2) Faculty of Wood and Paper Science, Gorgan University of Agricultural Sciences and Natural Resources, Gorgan (Iran); (3) Department of Wood and Paper Science and Technology, Faculty of Agriculture and Natural Resources, Islamic Azad University, Chalous Branch (Iran); (4) Institute of Tropical Forestry and Forest Products (INTROP), Universiti Putra Malaysia, UPM, 43400, Serdang, Selangor (Malaysia)

@ Hamid Reza Naji (hrn_16hrn@ilam.ac.ir)

Received: Apr 30, 2014 - Accepted: Jun 01, 2015

Citation: Naji HR, Nia MF, Kiaei M, Abdul-Hamid H, Soltani M, Faghihi A (2015). Effect of intensive planting density on tree growth, wood density and fiber properties of maple (Acer velutinum Boiss.). iForest 9: 325-329. - doi: 10.3832/ifor1333-008 [online 2015-10-22]

Communicated by: Giacomo Goli properties of different tree species, as demonstrated by Lei et al. (1997), Debell et al. (2002), and Naji et al. (2013) on red alder (Alnus rubra), poplar (Populus spp.), and rubberwood (Hevea brasiliensis), respectively. Numerous studies have examined the effects of silvicultural practices on wood properties of trees. Tree spacing is one of the most common stand parameter for controlling the tree growth. Suitable planting distances ensure the required space for tree growth, and optimize the biomass production per unit area (Harris 2007). However, it is not well-known how growth alters the wood and fiber characteristics in Acer. Therefore, knowing the relationship between planting density and tree and wood characteristics can help foresters maximize the biomass production without lessening in wood quality.

Fundamental knowledge on wood properties of Acer trees grown in short-rotation plantations and their variation under different silvicultural management regimes is limited. Few recent studies on Acer wood properties have focused on basic information about fiber and wood density (Kiaei et al. 2012). Relative changes in wood properties can be relevant for the forest industry (Tyrväinen 1995). Therefore, combining the information on several factors such as genetic entry, initial spacing, environmental conditions, and silvicultural management is important to better understand how they affect wood properties. 
To the best of our knowledge, there are no specific studies reporting measured tree growth parameters and wood properties of Acer at different planting densities. We hypothesized that the development of tree growth parameters, wood density, and wood cell characteristics are affected by differences in initial planting density. To examine this hypothesis, diameter at breast height, annual ring width, stem taper, wood density, and fiber properties of trees were evaluated in an Acer velutinum Boiss. plantation in northern Iran. Understanding the differences among trees in each plantation related to planting density will help to define the best strategy for managing plantations.

\section{Material and methods}

\section{Study description}

This study was carried out at the Shast Kalateh research and training forest, University of Gorgan (northern Iran), located between $36^{\circ} 44^{\prime} 4^{\prime \prime}$ to $36^{\circ} 47^{\prime} 47^{\prime \prime} \mathrm{N}$ and $54^{\circ}$ $21^{\prime} 57^{\prime \prime}$ to $54^{\circ} 24^{\prime} 16^{\prime \prime} \mathrm{E}$ (Ghanbari et al. 2013). About 57.3 ha of this Hyrcanian forest was allocated for Acer studies, mostly establishing a mono-cultural and intensively managed plantation of Persian maple (Acer velutinum Boiss.) in 1996. The plantation was originally designed to assess the effect of different planting densities (PD), namely 2500,4400 , and 10000 trees ha', on biomass production and different wood characteristics. The main criterion for comparison of these plots was planting density (number of trees per hectare). All three plots were located at an elevation range of 345-490 $\mathrm{m}$ a.s.l. with northern and northeastern facing slopes. The plots were geographically close to each other. The basic information of each planting site is summarized in Tab. 1.

\section{Tree form measurements}

Sampled tree height, tree diameter at different heights (DBH at $1.30 \mathrm{~m}$ above the ground level, $50 \%$ and $75 \%$ of tree height), and stem taper (ST) were measured for 30 trees at each planting density. Due to the densely-stocked plantation, tree height was difficult to measure, thus height measurements were taken only on cut trees, as described by Rodrigo et al. (2004) and Naji et al. (2013). Tree height and tree diameters over bark $(\mathrm{cm})$ were measured by a fabric tape (with $0.01 \mathrm{~cm}$ precision) and a diameter tape, respectively. ST is defined as the narrowing rate of diameter with regard to the increase in height of the tree (Gray 1956). The ST was determined by form quotients, i.e., the ratio of an upperstem diameter to the lower-stem diameter. ST was measured at first half of each tree height, and this section was divided into ten subsections of equal length (L/10). The diameter of each subsection was then measured at their bottom part. All measurements were performed over the bark. The ST was the average diameter at each subsection divided by the DBH. According to the diameter in each subsection, the narrowing rate of the stem was calculated as a percentage (Hjelm 2013, Steven \& Benee 1988).

\section{Sampling and measurements}

Four 12-year-old trees were randomly selected in each plot and then harvested at 15 $\mathrm{cm}$ above the ground (12 trees in total). The sampled trees had almost straight stems, exhibited a limited variation in DBH, and showed no obvious mechanical defects of stems or roots (based on visual inspection). Trees close to large gaps, accessible roads, or near the edge of each plot were excluded. Tree growth parameters are summarized in Tab. 1.

The harvesting design was carried out using a non-randomized complete block. From each tree, two 5-cm-thick discs were sampled at breast height to measure the annual growth ring width, wood density and fiber properties. The discs were labeled based on the plot, tree number, and the height of sampling and then moved to the wood anatomy laboratory at the University of Gorgan for further assessment.

\section{Wood basic density}

Wood sampling method and the general requirements for physical tests were in accordance with the ISO standard 3129-E (1975). The ISO standard 3131-E (1975) was used to measure the wood density. Two radial (bark to bark) wood segments of about $20 \mathrm{~mm}$ in width and $50 \mathrm{~mm}$ in height were collected from each disc. Two strips from bark toward pith in radial axis from each segment were cut. After removing the pith, two sample blocks with dimensions of $20 \times 20 \times 20 \mathrm{~mm}$ were taken from the inner, middle, and outer parts of the strips (with a total of 24 for each disc). The basic wood density $\left(\mathrm{g} \mathrm{cm}^{-3}\right)$ was calculated by dividing the oven-dried weight by the green volume of the sample blocks obtained using the water displacement method.

\section{Total annual ring width and fiber properties}

The second disc from each tree was used for measuring the annual ring width (ARW, $\mathrm{mm}$ ) and fiber properties. The annual growth rings of $A$. velutinum were clearly visible to the naked eye. The cross view of discs were cleaned and fine-sanded. The ARW was measured using a normal binocular (Rinntech, Heidelberg, Germany). The arithmetic mean of the ARWs from measurements at six points for each ring was considered as the mean annual radial growth rate of the tree.

\section{Microscopic images and fiber cell anatomy}

The second disc was also used for fiber anatomical measurements. As for the maceration process, we visually determined the growth rings and took every other ring from pith toward bark, with a total of six annual rings from each tree. The early- and latewood were collected together and some matchstick sized chips were carefully cut from the central part of both ring sections with a sharp cutter. The chips from each growth ring were placed into a separate test tube and submerged by Schulz's solution ( $50 \%$ nitric acid with a small amount of potassium chlorate). To accelerate the chemical maceration process, the test tubes were put in an oven at $70^{\circ} \mathrm{C}$ until a milky color appeared. Afterward, the acid was replaced by distilled water several times. The fibers were then stained in aqueous safranin for two hours. Free individual fibers were kept in glycerin as the mounting medium before examination under a microscope.

The fiber length ( $F L, \mu m)$, fiber diameter (FD, $\mu \mathrm{m}$ ), and fiber wall thickness (FWT, $\mu \mathrm{m})$ were measured from randomly selected fiber cells. FL and FD were measured under $100 \times$ magnification, while FWT was measured under $400 \times$ magnification. The average length and diameter of 50 fibers were measured using the image processing software package Qwin ${ }^{\oplus}$ (Leica Microsystems Imaging Solutions Ltd, Cambridge, UK).

\section{Statistical analysis}

All statistical analyses were performed with the software statistical package SPSS Statistics $^{\circledast}$ v. 17 for Windows. The data were subjected to one-way analysis of variance (ANOVA) followed by Duncan's multiple range test (DMRT) to test the effect of initial planting density on mean selected tree features, WD, ARW, and fiber properties with $\alpha=0.05$. The skewness and Shapiro-Wilk's tests were used to test for the normal distribution of data. In addition, the Levene's test was performed to test for the equality of variance.

Tab. 1 - Basic information of the A. velutinum plantation. (PD): planting density; (TH): tree height; (AP): annual precipitation.

\begin{tabular}{|c|c|c|c|c|c|c|c|c|c|c|}
\hline \multirow{2}{*}{$\begin{array}{c}\text { PD } \\
\left(\text { trees ha }^{-1}\right)\end{array}$} & \multirow{2}{*}{$\begin{array}{c}\text { Initial } \\
\text { spacing }(m)\end{array}$} & \multirow{2}{*}{ Symbol } & \multirow{2}{*}{$\begin{array}{l}\text { TH } \\
(\mathrm{m})\end{array}$} & \multirow{2}{*}{$\begin{array}{l}\text { Elevation } \\
\text { (m a.s.l.) }\end{array}$} & \multicolumn{3}{|c|}{ Temperature $\left({ }^{\circ} \mathrm{C}\right)$} & \multirow{2}{*}{$\begin{array}{c}\text { AP } \\
(\mathrm{mm})\end{array}$} & \multirow{2}{*}{$\begin{array}{c}\text { Slope } \\
\text { (\%) }\end{array}$} & \multirow{2}{*}{ Soil texture } \\
\hline & & & & & Min & Max & Mean & & & \\
\hline 10000 & $1 \times 1$ & A & 13.80 & & & & & & & \\
\hline 4444 & $1.5 \times 1.5$ & B & 15.40 & $345-490$ & 6.7 & 25.2 & 17.8 & 649 & 10 & Silt-Clay to clay-loam \\
\hline
\end{tabular}



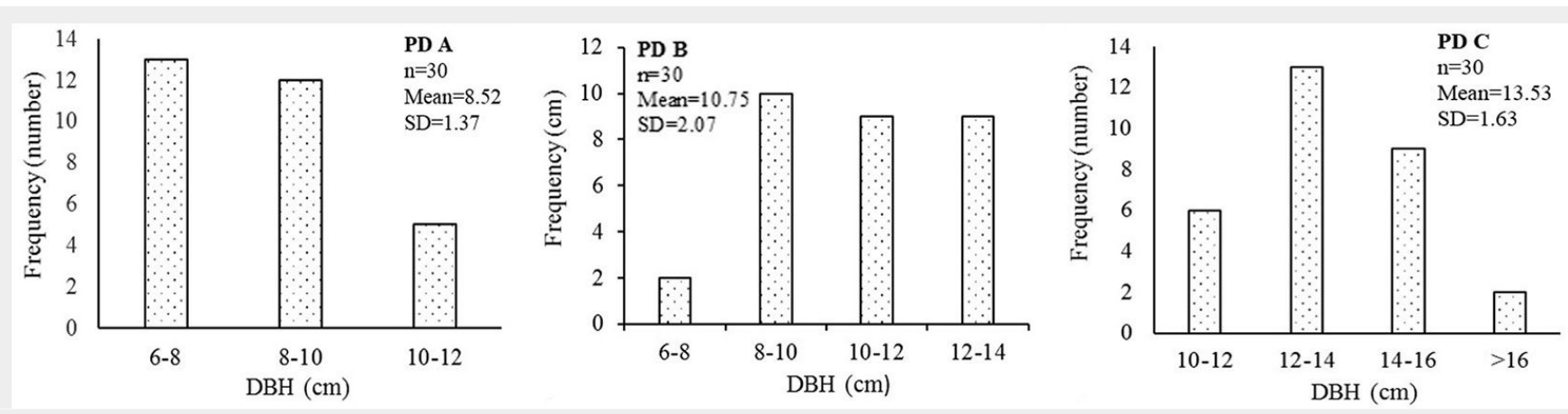

Fig. 1 - Number of trees in different DBH class at each planting density (PD). (A) 10000 trees ha'; (B) 4444 trees ha-1; and (C) 2500 trees ha ${ }^{-1} ;(n)$ : number of sampled trees in the stand; (Mean): mean DBH of all sampled trees in the stand; (SD): standard deviation.

The relationship between the above-mentioned variables were determined by Pearson's correlation coefficient (Pallant 2011).

\section{Results}

Diameter at breast height, annual ring width, and stem taper

Data for mean $\mathrm{DBH}$, annual ring width (ARW), and stem taper (ST) are summarized in Tab. 2. The distribution of $D B H$ in each PD is shown in Fig. 1. As expected, initial PD had a significant and negative effect on the DBH, which showed an increasing trend with decreasing PD. The DBH ranged between 6.57-10.23 mm, 8.88-13.89 mm, and 10.56-16.02 $\mathrm{mm}$ in PDs $A, B$, and $C$, respectively. The mean DBHs of PDs $B$ and $C$ showed no significant difference to each other $(p>0.05)$, while they were significantly different of PD A $(p<0.05)$. The mean DBH of PD $C$ was $58.8 \%(5.01 \mathrm{~cm})$ higher than that for PD A.

The average total annual ring width (ARW) at $1.3 \mathrm{~m}$ height increased from high to low PDs (Tab. 2) and ranged from 2.004.90 mm, 2.50-6.00 mm, and 2.90-6.70 mm for PDs A, B, and C, respectively. Initial planting densities significantly affected ARW $(p<0.05)$. The average ARW in PD C was significantly greater than in other PDs (Tab. 2). The patterns of radial variation as a function of cambial age were similar at all PDs, with an increasing growth rate until 78 years of cambial age; afterward, the growth rate started decreasing gradually with age to about 11-12 years. For PD B, the trend seems little different with a maximum at $4^{\text {th }} y$ rs. (Fig. 2).

The effect of PD on the rate of ST can be clearly inferred from the results reported in Tab. 2. ST was not found to differ $(p>0.05)$ among different planting densities, indicating that initial PDs had no significant effect on this factor. However, the lowest ST value was observed at highest PD (10000 trees $\left.\mathrm{ha}^{-1}\right)$ with a clear increasing pattern toward the lowest PD (2500 trees ha-1).

\section{Wood density (WD) and fiber anatomy}

The average WDs observed at the three PDs were within a close range (Tab. 2), showing a similar variation among trees (0.43-0.65 $\left.\mathrm{gr} \mathrm{cm}^{-3}\right)$. Although there was a gradual trend of WD increase from high to low PDs, the analysis of variance showed no significant differences ( $p>0.05)$ among different initial planting densities.

The fiber properties measured at the three PDs did not vary significantly. The average FL, FD, and FWT showed similar ranges of variation. The $\mathrm{FL}$ showed the shortest mean value of $689 \mu \mathrm{m}$ in PD C and the longest of $1080 \mu \mathrm{m}$ in PD A, FD ranged from $16.91 \mu \mathrm{m}$ in PD B up to $23.25 \mu \mathrm{m}$ in PD $A$, and FWT was the thinnest in PD C with $3.22 \mu \mathrm{m}$ and the thickest in PD A with 5.25 $\mu \mathrm{m}$.

Relationships between tree features, wood density, and wood anatomical properties

The Pearson's correlation analysis bet-

ween tree features, WD, and fiber anatomical properties in A. velutinum showed no pairwise significant correlations among the examined parameters. According to the correlation results, regression analysis could not be applied to fit the presented data.

\section{Discussion}

In this study, three plots with different initial planting densities were established to investigate the importance of tree spacing on Acer velutinum growth and yield. In addition, the effect of planting density on some Persian maple stem features was quantified and tested. Previous studies have been reported on the variation of tree growth features, stand production, and wood characteristics under different

Tab. 2 - Mean ( \pm standard deviation) of tree characteristics, fiber properties, and wood density of the sampled trees at three planting densities (PD) of rubberwood in Acer velutinum. (DBH): diameter at breast height; (ARW): total annual ring width; (ST): stem taper; (WD): wood density; (FL): fiber length; (FD): fiber diameter; (FWT): fiber wall thickness. Means in the same row (in different PDs) followed by the same letter are not significantly different $(p>0.05)$ after Duncan's post-hoc test.

\begin{tabular}{lccc}
\hline Parameter & $\begin{array}{c}\text { PD A } \\
\left(10000 \text { trees ha }^{-1}\right)\end{array}$ & $\begin{array}{c}\text { PD B } \\
\left(4444 \text { trees ha }^{-1}\right)\end{array}$ & $\begin{array}{c}\text { PD C } \\
\left(2500 \text { trees ha }^{-1}\right)\end{array}$ \\
\hline DBH $(\mathrm{cm})$ & $8.52 \pm 1.19^{\mathrm{b}}$ & $10.75 \pm 1.79^{\mathrm{ab}}$ & $13.53 \pm 1.66^{\mathrm{a}}$ \\
ARW $(\mathrm{mm})$ & $3.30 \pm 1.08^{\mathrm{c}}$ & $4.27 \pm 1.14^{\mathrm{b}}$ & $5.54 \pm 1.21^{\mathrm{a}}$ \\
ST $(\%)$ & $0.42 \pm 0.05^{\mathrm{a}}$ & $0.43 \pm 0.08^{\mathrm{a}}$ & $0.52 \pm 0.07^{\mathrm{a}}$ \\
WD $\left.(\mathrm{g} \mathrm{cm})^{-3}\right)$ & $0.52 \pm 0.07^{\mathrm{a}}$ & $0.55 \pm 0.02^{\mathrm{a}}$ & $0.56 \pm 0.04^{\mathrm{a}}$ \\
FL $(\mu \mathrm{m})$ & $828.00 \pm 119^{\mathrm{a}}$ & $837.00 \pm 96^{\mathrm{a}}$ & $869.00 \pm 96^{\mathrm{a}}$ \\
FD $(\mu \mathrm{m})$ & $20.30 \pm 1.29^{\mathrm{a}}$ & $19.50 \pm 1.18^{\mathrm{a}}$ & $19.40 \pm 1.20^{\mathrm{a}}$ \\
FWT $(\mu \mathrm{m})$ & $4.20 \pm 0.54^{\mathrm{a}}$ & $4.00 \pm 0.35^{\mathrm{a}}$ & $3.90 \pm 0.33^{\mathrm{a}}$ \\
\hline
\end{tabular}

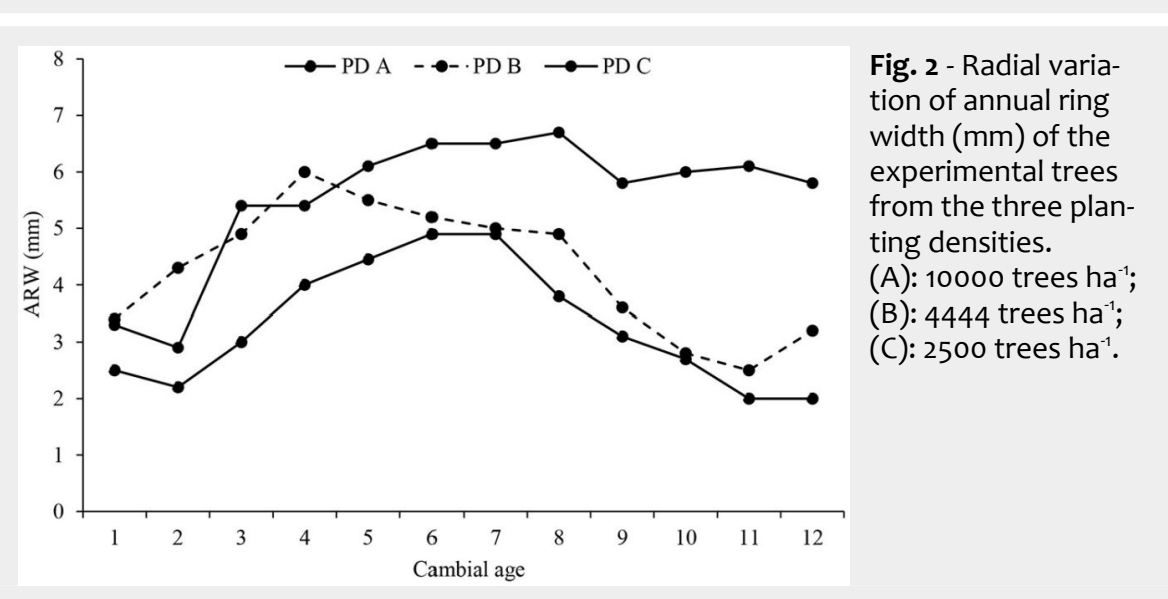


management strategies (Zobel \& Van Buijtenen 1989, Jiang et al. 2007, Naji et al. 2014). We found that high PD had a more pronounced effect on tree growth rather than on wood properties. The most obvious and significant differences in this study were between the lowest and the highest PDs. Trends in WD and fiber anatomical properties were quite similar among the three different PDs (Tab. 2).

\section{Effect of initial planting density on} diameter at breast height, annual ring width, and stem taper

In high-density plantations, the time required for canopy closure is shorter as compared to low-density stands, and this affects both growth increments and their pattern of variation (Ishiguri et al. 2005). In the present study, ARW increased in the first seven years and then declined (though a slightly different pattern was observed in PD B). This was likely due to crown enclosure and the increased competition among trees (Debell et al. 2004, Moya Roque \& Tomazello Fo 2007).

The mean DBH and ARW in low-density stands reached 13.53 and $5.54 \mathrm{~mm}$ in the last 12 years, clearly indicating a faster growth associated with significantly wider rings (Bhat \& Indira 1997). At such density, trees tend to increase their lateral growth (Fujiwara \& Yang 2000, Macdonald \& Hubert 2002, Naji et al. 2014) to efficiently exploit a larger amount of resources (sunlight, moisture and mineral elements). Furthermore, crown size in low PDs is another influential factor (Jiang et al. 2007). However, little significant variation in wood and tree properties among different planting densities could be detected after three to four decades (Ishiguri et al. 2005). Nonetheless, for commercial purposes higher amounts of woody biomass are produced at higher planting densities, while highquality wood is usually obtained by establishing low-density plantations (Naji \& Sahri 2012).

In general, ARW depends on tree vigor, planting density, and environmental conditions (Pape 1999a, 1999b, Ishiguri et al. 2005). Our results showed a decrease in the maximum ring width after the seventh year since plantation that could be related to crown closure, according to Ishiguri et al. (2005). From this age onward, height growth prevails and the shading of lateral branches reduces both crown diameter and radial growth. These conditions may favor several advantageous characteristics of trees in terms of decreasing the size of knotty core, taper rate, and a more uniform wood (Punches 2004).

Generally, trees with smaller crown size growing in high-density plantations or with slow growth rate are expected to yield more cylindrical stems and smaller taper. Stem straightness considerably impacts yield and quality of wood and fiber products (Zobel \& Van Buijtenen 1989). Surprisingly, we found no differences in stem tapers, that resulted unaffected by changes in the PDs. Changes in stem shape may be restricted to trees growing at lower PDs. In addition, all PDs were highly crowded with huge competition among trees since the establishment. Therefore, it may be hypothesized that alteration in stem shape is less evident at higher PDs and at lower age.

\section{Effect of initial planting density on} wood density and fiber anatomical properties

Variation of wood density with stand density is still a controversial issue. Direct relationships in Eucalypts (Zobel 1992), no relationship in Eucalypts (Schönau 1973) and red Alder (Lei et al. 1997), as well as indirect and no relationships in Hevea with low and high planting densities, respectively (Naji et al. 2014) have been reported. In this study, no significant differences in wood density were detected among different PDs, though marked differences in growth rates (ARW) between low and high PDs were detected (Tab. 1). The most likely reason for these contradictions could be related to a similar effect of the intensive planting density on most wood properties. In addition, we averaged ARW over 12 rings in a disc, and the effect could be stronger than for a given single ring. On the other hand, it is known that wood density in most diffuse-porous species is mainly associated to anatomical properties (Panshin \& De Zeeuw 1980).

In the present study, high planting densities were not associated with significant changes in fiber anatomical characteristics. The FL, FD, and FWT were not depressed by increased growth rate (stem diameter). Similar results have been reported for Populus (Holt \& Murphey 1978, cited in Lei et al. 1997, Jiang et al. 2007), red Alder (Lei et al. 1997), Eucalypt (Harris 2007), and Hevea with weak variation (Naji et al. 2013). Thus it can be concluded that in general fiber dimensions do not reveal a plastic reaction to changes in environmental conditions due to variation in planting density (Harris 2007). Prior studies reported that variation of fiber anatomical properties are controlled by genetic features (Zobel \& Van Buijtenen 1989). However, the effect of stand density on the anatomical characteristics of fibers can decline remarkably in the case of overcrowded densities. Indeed, Naji et al. $(2013,2014)$ argued that effect of stand density on fiber characteristics in Hevea could be more pronounced at low rather than at high planting density.

An important result of this study was the lack of significant difference in wood density and fiber anatomical features between the three planting densities, despite the observed variation in yield and biomass produced per unit area. Based on our results, higher planting densities can be established in Acer velutinum plantations in order to achieve more biomass with almost the same wood quality obtainable by ap- plying lower densities. This implies a greater wood production in shorter rotation periods for downstream industries (Naji \& Sahri 2012, Naji et al. 2014). However, higher planting density entails also nutrient depletion of soil, which in turn affects tree growth. Poor or depleted soils should be properly treated with fertilizers.

\section{Correlation between tree growth} features, wood density, and fiber anatomical properties

Correlation analysis showed no significant relationship between tree growth features, wood density, and fiber anatomical properties in Acer velutinum. In general, high initial density, especially for diffuse-porous trees, was reported to have no or deleterious effects on wood properties (Zobel \& Van Buijtenen 1989, Weber \& Sotelo Montes 2010). In this study, we did not found any of such effects, and this could be due to the fact that all the three initial PD considered were so high that a similar effect was induced on trees. Our findings are consistent with the results of Radcliffe (1953) and Ishiguri et al. (2005) who found no correlation between annual ring widths (growth rate), wood density, and fiber properties in maple wood.

\section{Conclusion}

The variation of tree growth, wood density and fiber properties were investigated under different intensive planting densities in a plantation of Acer velutinum. No prior study provided comprehensive evidence measuring the influence of Acer velutinum tree traits on the wood density and fiber properties.

This study demonstrated that the initial planting density had different effects on tree growth parameters and wood characteristics in maple. DBH and ARW were affected by planting density, with the highest values for such parameters recorded at extreme PD. Contrastingly, for stem taper, wood density and fiber properties, no significant changes among different planting densities were detected.

The findings of this study support the practice of increasing the initial density in short rotation plantations of Acer velutinum as a suitable strategy to increase tree growth and wood biomass while retaining at the same time good technological characteristics of wood for downstream industries.

\section{Acknowledgements}

HRN wrote the manuscript and carried out all statistical analyses. MFN carried out the field works. MK, HAH, MS, and AR developed the research concept, reviewed and provided comments to the manuscript. This research was partially supported by the Gorgan University of Agricultural Sciences and Natural Resources, Golestan, Iran.

\section{References}

Bhat KM, Indira EP (1997). Effect of faster 
growth on timber quality of teak. KFRI Research Report 132, Kerala, India, pp. 61.

Chaffey N (2002). Why is there so little research into the cell biology of the secondary vascular system of trees? New Phytologist 153: 213-223. doi: 10.1046/j.0028-646X.2001.00311.x

Clark A, Jordan L, Schimleck L, Daniels RF (2008). Effect of initial planting spacing on wood properties of unthinned loblolly pine at age 21. Forest Products Journal 58 (10): 78-83. [online] URL: http://search.proquest.com/openview/65 026b2c146d6e8fcf95f8f1156184d6/1

Debell DS, Singleton R, Harrington CA, Gartner $B L$ (2002). Wood density and fiber length in young Populus stems: relation to clone, age, growth rate, and pruning. Wood and Fiber Science 34 (4): 529-539. [online] URL: http://ir. library.oregonstate.edu/xmlui/handle/1957/1394 6

Debell DS, Singleton R, Gartner BL, Marshall DD (2004). Wood density of young-growth western hemlock: relation to ring age, radial growth, stand density, and site quality. Canadian Journal of Forest Research 34: 2433-2442. doi: 10.1139/x04-123

Fallah nia M (2009). Effect of planting distance on fiber morphology and physical properties of maple (Acer velutinum). MSc thesis, Faculty of Wood and Paper Science, University of Gorgan, Gorgan, Iran, pp. 85.

Fujiwara S, Yang KC (2000). The relationship between cell length and ring width and circumferential growth rate in five Canadian species. IAWA Journal 21 (3): 335-345. - doi: 10.1163/2294 1932-90000251

Gray HR (1956). The form and taper of foresttree stems. Paper No. 3, Imperial Forestry Institute, University of Oxford, Oxford, UK, pp. 84. [online] URL: http://www.bodley.ox.ac.uk/user s/millsr/isbes/ODLF/IP32.pdf

Ghanbari F, Shataee Sh Habashi H, Ayoubi S (2013). Possibility of investigation on spatial estimation of density and mean diameter of forest trees using terrain analysis (Case Study: Dr. Bahramnia Forestry Plan, District I, Gorgan, Iran). Journal of Wood and Forest Science and Technology 19 (4): 41-57. [in Farsi]

Harris FC (2007). The effect of competition on stand, tree, and wood growth and structure in subtropical Eucalyptus grandis plantations. PhD thesis, Southern Cross University, Lismore, NSW, Australia, pp. 193. [online] URL: http:// epubs.scu.edu.au/theses/125/

Hjelm B (2013). Stem taper equations for poplars growing on farmland in Sweden. Journal of Forestry Research 24 (1): 15-22. - doi: 10.1007/s116 76-012-0270-4

Holt DH, Murphey WK (1978). Properties of hybrid poplar juvenile wood affected by silvicultural treatments. Wood Science 10: 198-203. ISO standard 3129 (1975). Wood - Sampling me- thods and general requirements for physical and mechanical tests. International organization for standardization, Geneva, Switzerland, pp. 1-4.

ISO standard 3131 (1975). Wood - Determination of density for physical and mechanical tests. International Organization for Standardization , Geneva, Switzerland, pp. 1-2.

Ishiguri I, Kasai S, Yokota S, lizuka K, Yoshizawa $\mathrm{N}$ (2005). Wood quality of Sugi (Cryptomeria japonica) grown at four initial spacings. IAWA Journal 26 (3): 375-386. - doi: 10.1163/2294193290000122

Jiang $\mathrm{ZH}$, Wang $\mathrm{XQ}$, Fei $\mathrm{BH}$, Ren $\mathrm{HQ}$, Liu XE (2007). Effect of stand and tree attributes on growth and wood quality characteristics from a spacing trial with Populus xiaohei. Annals of Forest Science 64: 807-814. - doi: 10.1051/forest:20 07063

Kiaei M, Bakhshi R, Veylaki S (2012). Determination of fiber length and juvenile and mature wood zones in Acer velutinum Boiss. trees grown in Iran. Forest Study in China 14 (4): 323326. - doi: 10.1007/s11632-012-0406-9

Lei H, Gartner LB, Milota MR (1997). Effect of growth rate on the anatomy, specific gravity, and bending properties of wood from 7-yearold red alder (Alnus rubra). Canadian Journal of Forest Research 27: 80-85. - doi: 10.1139/x96-165 Macdonald E, Hubert J (2002). A review of the effects of silviculture on timber quality of Sitka spruce. Forestry 75 (2): 107-139. - doi: 10.1093/fo restry/75.2.107

Moya Roque R, Tomazello Fo M (2007). Wood density and fiber dimensions of Gmelina arborea in fast growth trees in Costa Rica: relation to the growth rate. Investigación agraria, Sistemas y recursos forestales 16 (3): 267-276. doi: 10.5424/srf/2007163-01015

Naji HR, Sahri MH (2012). Intra- and inter-clonal tree growth variations of Hevea brasiliensis. Journal of Forestry Research 23 (3): 429-434. doi: 10.1007/s11676-012-0280-2

Naji HR, Sahri MH, Nobuchi T, Bakar ES (2013). Intra- and interclonal variation in anatomical properties of Hevea brasiliensis Muell. Arg. Wood and Fiber Science 45 (3): 268-278.

Naji HR, Bakar ES, Soltani M, Ebadi SE, AdulHamid H, Karbalaei S, Sahri MH (2014). Effect of initial planting density and tree features on growth, wood density and anatomical properties from a Hevea brasiliensis trial plantation. Forest Products Journal 64 (1-2): 41-47. - doi: 10.13073/FPJ-D-13-00071

Pape R (1999a). Effects of thinning on wood properties and stem quality of Picea abies. Scandinavian Journal of Forest Research 14: 3850. - doi: $10.1080 / 02827589908540807$

Pape R (1999b). Influence of thinning and tree diameter class on the development of basic density and annual ring width in Picea abies.
Scandinavian Journal of Forest Research 14 (1): 27-37. - doi: 10.1080/02827589908540806

Pallant J (2011). SPSS survival manual: a step by step guide to data analysis using SPSS ( $4^{\text {th }}$ edn). McGraw Hill Education, Berkshire, UK, pp. 352. Panshin AJ, De Zeeuw CH (1980). Textbook of wood technology ( $4^{\text {th }}$ edn). McGraw-Hill, New York, USA, pp. 722. [online] URL: http://www. cabdirect.org/abstracts/19810669130.html

Punches J (2004). Tree growth, forest managements and their implications for wood quality. PNW 576, Oregon State University, A Pacific Northwest Extension Publication, Corvallis, OR, USA, pp. 1-8.

Radcliffe BM (1953). The influence of specific gravity and rate of growth upon the mechanical properties of sugar maple in flexure. Station Bulletin no. 597, Purdue University, Agricultural Experiment Station, Lafayette, IN, USA, pp. 26. [online] URL: http://krishikosh.egranth.ac.in/HD /common/split_document.jsp?doc=41387.pdf Rodrigo VHL, Silva TUK, Munasinghe ES (2004). Improving the spatial arrangement of planting rubber (Hevea brasiliensis Muell. Arg.) for longterm intercropping. Field Crops Research 89: 327-335. - doi: 10.1016/j.fcr.2004.02.013

Schönau AP (1973). The effect of planting spacement and pruning on growth, yield and timber density of Eucalyptus grandis. Journal of South African Forestry 88: 16-23. - doi: 10.1080/003821 67.1974.9629319

Steven BJ, Benee FS (1988). Stem form changes in un-thinned slash and loblolly pine stands following mid-rotation fertilization. Southern Journal of Applied Forestry 12 (2): 90-97. [online] URL: http://www.ingentaconnect.com/con tent/saf/sjaf/1988/00000012/00000002/artoooo 7

Tyrväinen J (1995). Wood and fiber properties of Norway spruce and its suitability for thermomechanical pulping. Acta Forestalia Fennica 249: 1-55. [online] URL: https://helda.helsinki.fi/ handle/10138/27281

Weber JC, Sotelo Montes C (2010). Correlations and clines in tree growth and wood density of Balanites aegyptiaca (L.) Delile provenances in Niger. New Forests 39: 39-49. - doi: 10.1007/s110 56-009-9153-8

Yousef Zadeh H (2007). Maple seed sprouting and sapling production from 11 sites in Mazandaran forest. Journal of Wood and Forest Science and Technology 40: 465-469. [in Farsi]

Zobel BJ, Van Buijtenen JP (1989). Wood variation: its causes and control. Springer, Berlin, Heidelberg, Germany, pp. 362.

Zobel B (1992). Silvicultural effects on wood properties. IPEF International, Piracicaba, Brazil, vol. 2, pp. 31-38. [online] URL: http://www. ipef.br/PUBLICACOES/international/nro2/capo5. pdf 